\title{
Goiânia: entre a arquitetura e a crônica
}

Márcia Metran de Mello, por um lado, no que concerne às letras, é escritora, com várias publicações e prêmios; por outro, no que se refere à ciência, é graduada em Arquitetura e Urbanismo pela Universidade Católica de Goiás, com mestrado em Arquitetura e Urbanismo pela Universidade de São Paulo e doutorado em Sociologia pela Universidade de Brasília.

Estas duas dimensões importantes de sua vida integram densamente a busca pela compreensão de Goiânia a partir da Arquitetura e das crônicas presentes em Goiânia: cidade de pedras e de palavras, cuja base foi calcada na sua tese de doutorado sob a orientação da $\operatorname{Prof}^{\mathrm{a}} \operatorname{Dr}^{\mathrm{a}}$ Barbara Freitag.

O livro inicia-se com um lindo prefácio de Barbara Freitag, orientadora da tese de doutorado de Márcia Metran de Mello, em que se delinea, com poesia e profundidade, a discussão das linhas mestras que estruturam a análise, particularmente no que se refere à construção do método construído para o desvendamento da relação entre as pedras e as palavras. Segue-se uma breve apresentação, de Orlinda Carrijo Melo, em que são reiterados argumentos que justificam a leitura do texto, particularmente em relação à tradição de pesquisa de Márcia Metran acerca da discussão arquitetônica de Goiânia, iniciada em sua dissertação de mestrado.

É na introdução a autora apresenta os dilemas gerais de estudo de uma jovem capital brasileira, seguido de um breve e denso debate teórico sobre imaginário, fundamento principal de sua empreitada de leitura das pedras e das palavras.

O texto, então, se divide em duas partes, a primeira, em 5 capítulos, dedicada ao debate da arquitetura, a cidade de pedras; enquanto a segunda, dividida em 3 capítulos, apresenta a discussão das crônicas, dando conta da cidade de palavras.

Por fim, a autora nos brinda com considerações finais que recuperam o debate fundamental do viver na cidade, no imbricado contexto de representações da natureza, do rural, das águas, no mundo denso e profundo do cerrado brasileiro, particularmente o goiano.

\footnotetext{
${ }^{1}$ Doutor em Geografia Humana (USP). Professor junto ao Departamento de Geografia da Faculdade de Filosofia, Letras e Ciências Humanas e do Programa de Pós-Graduação em Integração da América Latina da Escola de Comunicações e Artes da Universidade de São Paulo e Pesquisador Associado da Biblioteca Brasiliana Mindlin. E-mail: jcsuzuki@usp.br.
} 


\section{REFERÊNCIA}

MELLO, Márcia Metran de. Goiânia; cidade de pedras e de palavras. Goiânia: UFG, 2006.

Recebido em 07/05/2017.

Aceito em 05/08/2017.

Publicado em 02/01/2018. 